\title{
Evaluation of Multiple Drug Using Status by Sociodemographic Characteristics of Individuals with Chronic Disease
}

\author{
Kronik Hastalığı Olan Bireylerin Çoklu İlaç Kullanım Durumlarının \\ Sosyodemografik Özelliklerine Göre Değerlendirilmesi \\ Burcu Kayhan Tetik*1, Işılay Gedik Tekinemre ${ }^{1}$, Hacer Gözde Güll ${ }^{1}$, Burak Mete ${ }^{2}$, Samima Hassanlı ${ }^{3}$, Wadee Alhuraibi ${ }^{3}$
}

\begin{abstract}
Introduction: The most common belief in traditional medicine is necessarily needed to prescribe a drug. Studies show two-thirds of medical examinations are ended up with the prescription. In this study, our aim is showing the effects and features of polypharmacy on chronic disease patients and assess the sociodemographic properties, create awareness about them. Method: This descriptive cross-sectional study is done with 340 patients who admit Inonu Unıversity Turgut Ozal Medicine Centre cardiology, pulmonary disease, neurology, family medicine and psychiatry policlinics. Statistical analysis is done with SPSS ver. 22.0 and in all tests p $<0.05$ level is accepted as statistically meaningful. Results: In our study, there are 333 participants and 154 of them are female $(46.2 \%) 179$ of them are male $(53.8 \%)$ and mean age is 52.37 . Eighty participants are 65 years old or over. When we evaluate the chronic disease patients, the most common diagnoses are heart disease which is seen in 177 (52.1\%) of participants and hypertension which is seen in 176 of participants (51.8\%). 184 of participants $(54.1 \%)$ are using less than 5 drugs and 149 of participants (43.8\%) are using more than 5 drugs. In the comparison of multidrug using and suffer from side effects, 50 of less than 5 drugs using participants (27.2\%) and 29 of more than 5 drugs using participants (19.5\%) had adverse effects, this difference is not statistically meaningful $(\mathrm{p}=0.100)$. Conclusion: We are in thought of family physicians can lower multi-drug using rates collaborating with patients for managing both acute and chronic diseases in our country where the cost of drugs are rising day by day. Because of that sociodemographic properties and drugs should be questioned for all the policlinics appeal of chronic disease patients and the cessation of drugs should be done according to the proper guidelines, they should be warned about drug interaction and how to use it.
\end{abstract}

Keywords: Chronic disease, polypharmacy, patient education

Giriş: Geleneksel tıpta en yaygın inanış bir hekim muayenesine gidildikten sonra mutlaka ilaç yazılması gerektiğidir. Yapılan çalışmalarda hekim muayenelerinin yaklaşık üçte ikisi reçete yazılması ile sonuçlanmaktadır. Bu çalışmada amacımız kronik hastalığı olan bireylerde çoklu ilaç kullanımının özelliklerini, bireyin sosyodemografik özelliklerine göre değerlendirmek ve bu konuda farkındalık yaratmaktır. Yöntem: Kesitsel tanımlayıcı olan çalışma, İnönü Üniversitesi Turgut Özal Tıp Merkezi Hastanesi'nin Aile hekimliği, Kardiyoloji, Gögüs hastalıkları, Nöroloji ve Psikiyatri polikliniklerine müracaat eden 340 hastada yapılmıştır. Verilerin istatistiksel değerlendirilmesi SPSS ver. 22.0 yazılımı ile yapılmış ve tüm testlerde p $<0.05$ istatistiksel olarak anlamlı kabul edilmiştir. Bulgular: Çalışmada toplam 333 katılımcı mevcut olup, 154'i kadın (\%46,2), 179'i erkek $(\% 53,8)$ ve yaş ortalaması 52.37 yıl idi.80 kişi (\%23.5) 65 yaş ve üzerindeydi. Kronik hastalığı olan bireylerin hastalıkları sorgulandığında en çok 177 kişi $(\% 52,1)$ kalp hastalığı ve $176(\% 51,8)$ inde hipertansiyon tanısı mevcuttu. Katılımcıların 184'ü $(\% 54,1)$ 5'den az ilaç kullanırken, 149'u $(\% 43,8) 5$ ve üzeri ilaç kullanmaktaydı. Çoklu ilaç kullanım durumlarıyla yan etki görülme durumları kıyaslandığında 5 ten az ilaç kullananların 50 ' si $(\% 27,2)$, 5 ve üzeri ilaç kullananların 29 ' u (\%19,5) yan etki gördüğünü ifade etmiş bu fark istatistiksel olarak anlamsız bulunmuştur ( $\mathrm{p}=0.100)$. Sonuç: İlaç maliyetinin her geçen gün arttı̆̆ ülkemizde aile hekimlerinin hastasıyla iş birliği yaparak hastasının hem akut hem kronik hastalıklarını aynı anda yöneterek çoklu ilaç kullanım oranlarını düşürebileceği kanaatindeyiz. $\mathrm{Bu}$ nedenle kronik hastalığı olan bireylerin polikliniğe her müracaatında sosyodemografik özellikleriyle kullandıkları ilaçlar sorgulanmalı, kılavuzlar eşliğinde gereksiz kullandığı ilaçlar kesilmeli ve etkileşime girebilecek ilaçlar konusunda hasta uyarılarak, ilaçları nasıl kullanacağı hakkında gerekli bilgilendirme yapilmalıdır.

Anahtar kelimeler: Kronik hastalık, çoklu ilaç kullanımı, hasta eğitimi

Received / Geliş tarihi: 29.06.2017, Accepted / Kabul tarihi: 08.10.2017

${ }^{1}$ Inönü University Medical Faculty, Department of Family Medicine

${ }^{2}$ Inönü University Medical Faculty, Department of Public Health

${ }^{3}$ Inönü University Medical Faculty, 1. Class Student

*Address for Correspondence / Yazışma Adresi: Burcu Kayhan Tetik. Inönü University Medical Faculty, Department of Family Medicine, Malatya-

TURKEY. E-mail: drburcukayhan@hotmail.com

Tetik BK, Tekinemre IG, Gül HG, Mete B, Samima Hassanlı S, Alhuraibi W. Evaluation of Multiple Drug Using Status by Sociodemographic Characteristics of Individuals with Chronic Disease. TJFMPC, 2018;12(1): 13-18. DOI: 10.21763/tjfmpc.399950 


\section{INTRODUCTION}

Polydrug use can be named as taking two or more drugs at the same time. ${ }^{1}$ Drug-using is increasing with age and being the important public health issue. In Ireland $21.9 \%$ of the aged population is taking more than 10 drugs are reported and this increase is associated with encouraging the guidelines for polydrug using. ${ }^{2}$ Polydrug using cause many problems like drug interaction, adverse effect, elimination difficulties and patient compliance. The human lifespan is much longer because of health improvement, preventive medicine and using modern technologies in nowadays than used to be. So, the population structure of countries is started to change and the ratio of aged individuals in general population is increased. As multidrug using can be needed for treatment of a disease, sometimes it can be because appealing of to the same patient with the same complaint to more than one doctor and so prescription of the similar drug. This situation cause may problems like drug adverse reactions, drug interactions treatment incompatibility. Multidrug using is a big problem especially, in geriatric patients. Because of modern dietary pattern or environmental factors, chronic diseases can come out at early ages, even more than one disease can be at same time. So lowering the drug number of patients who have multi health problems or using combined preparations are emphasized in nowadays. ${ }^{3}$

In this study, our aims are to evaluate the properties of multidrug using individuals with chronic diseases on basis of sociodemographic features and create awareness.

\section{METHOD}

Ethical approval of our study, which is descriptive and cross-sectional, has taken from Inonu University Science Research And Publication Ethics Board by 2017/13--5 decision number. Totally 340 patients who admitted Inonu University Turgut Ozal Medicine Center Cardiology, Pulmonary Disease, Family Medicine, Neurology and Psychiatry Policlinics at 8-10 June 2017 and were agreed to be part of our study, was taken. A survey which has 19 question was done with face to face technique after took the consents of participants. Individuals with no consent for study, have no chronic disease or has a psychiatric disease which causes not to understand the question in the survey, answered wrong or missing, younger than eighteen years old are excluded form the study. In survey paper there were questions for sociodemographic properties (age, gender, marital status, education level, occupation, monthly income, living alone or with whom he lived) what are the chronic diseases, how many drugs he use, have any child, whether living together with them, who gives the drugs, whether he goes checks-up regularly and adverse events he has or not. The number of patients' drugs are categorized into two group like less than five and five or more to determine multi-drug using rate by examining the literature. Data are statistically analyzed with SPSS for Windows version 22.0. For qualitative variables, arithmetic mean (X) and standard deviation, for quantitative variables numbers (n) and percent (\%) were used. Comparing the quantitative variables Pearson chi-square test was used and in all tests $\mathrm{p}<0.05$ is accepted as statistically meaningful.

\section{RESULTS}

There are 333 participants in this study and 154 of them $(46.2 \%)$ are female, 179 of them $(53.8 \%)$ are male. Mean age was 52.37, and 80 of them are sixtyfive years old or over. When education levels are compared 93 of participants $(27.4 \%)$ are uneducated. And 52 of them $(15.3 \%)$ are college graduate. On basis of occupation 135 of them are retired (44.3\%), 122 of them $(35.9 \%)$ are housewifes. Sociodemographic features of participants are shown in table 1.

When we evaluate the chronic disease patients, the most common diagnoses are heart disease which is seen in 177 (52.1\%) of participants and hypertension which is seen in 176 of participants $(51.8 \%)$.

184 of participants $(54.1 \%)$ are using less than 5 drugs and 149 of participants $(43.8 \%)$ are using more than 5 drugs.

There was no statistically meaningful difference between with comparing the drug adverse effects on groups one have chronic disease and the other has not $(\mathrm{p}=0.112)$. In comparison with the age of 65 , there were adverse effects in 68 participants over 65 years old and 14 participants under 65 years old. But it is not statistically significant $(\mathrm{p}=0.114)$. $81.9 \%$ of patients younger than 65 years and $86.3 \%$ of patients older than 65 years went to their examinations regularly. but no statistical difference was found $(\mathrm{p}=0.590)$. No statistically significant difference was found when we compared patients older than 65 years with respect to multiple drug $\mathrm{use}(\mathrm{p}=0.166)$. This situation is shown in table 2 .

Table 3 shows multidrug using and sociodemographic data.

Comparing multidrug using and having adverse event, 50 patients $(27.2 \%)$ of using below 5 drugs and 29 patients $(19.5 \%)$ of using over 5 drugs mentioned have an adverse event, and this difference is not statistically meaningful. $(\mathrm{p}=0.100) .150$ of using less than 5 drugs $(81.5 \%)$ mentioned going checkups 
Table 1. Sociodemographic features of participants

\begin{tabular}{|c|c|c|}
\hline Gender & Number & Percent $(\%)$ \\
\hline Female & 154 & 46.2 \\
\hline Male & 178 & 53.8 \\
\hline $\begin{array}{l}\text { Marital Status } \\
\text { Married } \\
\text { Single }\end{array}$ & $\begin{array}{c}286 \\
47\end{array}$ & $\begin{array}{l}85.3 \\
14.7\end{array}$ \\
\hline $\begin{array}{l}\text { Education Status } \\
\text { Illiterate } \\
\text { Primary School } \\
\text { Middle School } \\
\text { High School } \\
\text { University }\end{array}$ & $\begin{array}{c}91 \\
104 \\
48 \\
39 \\
51\end{array}$ & $\begin{array}{l}27.4 \\
31.2 \\
14.4 \\
11.8 \\
15.3\end{array}$ \\
\hline $\begin{array}{l}\text { Occupation } \\
\text { Retired } \\
\text { Housewife } \\
\text { Private Sector } \\
\text { Office Worker }\end{array}$ & $\begin{array}{c}133 \\
120 \\
43 \\
37\end{array}$ & $\begin{array}{l}39.7 \\
35.9 \\
13.2 \\
11.2\end{array}$ \\
\hline $\begin{array}{l}\text { Monthly Income } \\
1000 \mathrm{TL} \\
1001-3000 \mathrm{TL} \\
3001-5000 \mathrm{TL} \\
\text { Above 5001 TL }\end{array}$ & $\begin{array}{c}139 \\
152 \\
33 \\
4\end{array}$ & $\begin{array}{c}41.5 \\
45.3 \\
10.3 \\
1.5\end{array}$ \\
\hline
\end{tabular}

Table 2. Multidrug using situations of below and over age 65 patients

\begin{tabular}{ccc}
\multicolumn{1}{c}{ Age } & $\mathbf{1 - 4}$ & $\mathbf{5}$ and average \\
& medicine & medicine \\
& $\mathbf{n} /(\boldsymbol{\%})$ & $\mathbf{n} /(\mathbf{\%})$ \\
Under 65 years & $135 /(53.1)$ & $119 /(46.9)$ \\
Over 65 years & $49 /(61.3)$ & $31 /(38.7)$ \\
\hline
\end{tabular}

regularly. And 157(85.3\%)of them mentioned taking drugs themselves. There are no statistically meaningful results in both of two comparisons (regularly of $\mathrm{p}=0.369, \mathrm{p}=0.718$ ).

\section{DISCUSSION}

In traditional medicine, the most common belief is needs to prescribe drug necessarily. Studies showreport that two third of medical examinations ended up with prescription. ${ }^{4}$ Multidrug using can be named as using 2 or more drugs ${ }^{1}$, when literature is checked polypharmacy is named as using 5 or more drugs. ${ }^{1,2,4}$
Polypharmacy rate is reported $13 \%$ in a study done in ABD. In studies which are done in our country, drug using rates are reported as $17.2 \%$ and $69 \%{ }^{3,5} \mathrm{In}$ our study, polypharmacy rate is $43.8 \%$, and this high rate is being associated with this survey has done at the tertiary center were referred more complicated cases and also, included cases based on having chronic disease not to base on age. As a result, polypharmacy can be much more in chronic diseases than the others.

It is found that polypharmacy is more common in man at abroad studies. ${ }^{6,7,8}$ In our country Cakmur et al. found polypharmacy is more common in female and this situation is associated with female participants are two folds of male participants, 
Table 3. Multidrug using and sociodemographic data

\begin{tabular}{|c|c|c|c|}
\hline Gender & $\begin{array}{c}1-4 \\
\text { medicine } \\
(\mathbf{n}) /(\%)\end{array}$ & $\begin{array}{c}5 \text { and average } \\
\text { medicine } \\
(\mathbf{n}) /(\%) \\
64(41.0) \\
85(48.0)\end{array}$ & $\begin{array}{c}\mathbf{p} \\
0.200\end{array}$ \\
\hline $\begin{array}{l}\text { Female } \\
\text { Male }\end{array}$ & $\begin{array}{c}92 /(59.0) \\
92(52.0) \\
\end{array}$ & & \\
\hline $\begin{array}{l}\text { Marital Status } \\
\text { Married } \\
\text { Single }\end{array}$ & $\begin{array}{c}153(53.9) \\
31(63.3)\end{array}$ & $\begin{array}{c}131(46.1) \\
18(36.7)\end{array}$ & 0.222 \\
\hline $\begin{array}{l}\text { Education Status } \\
\text { Illiterate } \\
\text { Primary School } \\
\text { Middle School } \\
\text { High School } \\
\text { University }\end{array}$ & $\begin{array}{l}54(58.1) \\
56(52.8) \\
20(43.5) \\
27(67.5) \\
27(56.3)\end{array}$ & $\begin{array}{l}39(41.9) \\
50(47.2) \\
26(56.5) \\
13(32.5) \\
21(43.7)\end{array}$ & 0.229 \\
\hline $\begin{array}{l}\text { Occupation } \\
\text { Retired } \\
\text { Housewife } \\
\text { Private Sector } \\
\text { Office Worker }\end{array}$ & $\begin{array}{l}68(51.5) \\
72(60.0) \\
27(60.0) \\
17(47.2)\end{array}$ & $\begin{array}{l}64(48.5) \\
48(40.0) \\
18(40.0) \\
40(52.8)\end{array}$ & 0.363 \\
\hline $\begin{array}{l}\text { Monthly Income } \\
1000 \mathrm{TL} \\
1001-3000 \mathrm{TL} \\
3001-5000 \mathrm{TL} \\
\text { Above 5001 TL }\end{array}$ & $\begin{array}{c}73(52.5) \\
84(55.6) \\
20(60.6) \\
2(40.0)\end{array}$ & $\begin{array}{c}66(47.5) \\
67(44.4) \\
13(39.4) \\
3(60.0)\end{array}$ & 0.255 \\
\hline
\end{tabular}

female lifespan is longer than male's and female patients come doctor's office more often. ${ }^{3,6,9}$ In some other studies found polypharmacy is more common in male. ${ }^{9,10}$ In our study number of male and female multidrug user participants are nearly equal though in male polypharmacy is found slightly more common.

Drug-using is much more in living alone than living with family is defined by Solmaz et al. ${ }^{11}$ But there are also other studies which refer the opposite situation, drug using is more in married the ones who have a child than single. ${ }^{5,9}$ In our study it is found that, multidrug using is slightly higher than living with family even statistically not meaningful like Solmaz et al. This situation may be due to married and child having individuals have much more duties on daily life so because of being more careful and following control of diseases better.

When drug using is examined on basis of education status, in studies done at Portugal, Ireland and Sweeden decrease the multidrug using as rising the education level is observed. ${ }^{9,11,12,13,14}$ In our study like all others there is the inverse relationship between with education level and multidrug use.
Hypertension is found the most common chronic disease in study of Peterson et al. ${ }^{15}$ In similar manner Taskin et al. have found hypertension is the most common chronic disease too. ${ }^{5}$ Likewise, antihypertension drugs are the number one in studies which are searching for which group of drugs is being used in chronic disease ${ }^{16,17,18,19,20,21}$. The most common chronic diseases are hypertension and chronic heart disease in our study too as support the literature. The reason for being number one drugs are cardiovascular group drugs in our study can be our study has done at tertiary hospital and included the patients who were admitted to cardiovascular outpatient clinics. Multidrug using and an adverse effects of them are more common in patients coming regularly check-up is indicated in national and international studies. ${ }^{9}$ In our study only $27.31 \%$ of patients going regularly checkup have an adverse effect and this situation is associated with going regularly check-up prevents using over the counter drugs and possible side effects of them. 
$88 \%$ of the participants in Taskin et al. mentioned that they get drugs by themselves but there is no data about what percent of them has an adverse effect. ${ }^{5}$ In our study $81 \%$ of participants are taking drugs by themselves and only $22.8 \%$ of them has adverse effect. This situation is associated with patients who get drugs by themselves are more carefully and follow the control of disease much better, because of no enough data in literature about that

Multidrug using is more common in chronic disease patients especially at older than age 65 . This situation is affiliated with both diseases which are appeared by the age gets older and because of drugs which are added to reduce adverse effects of already using drugs. In a survey it is seen that multidrug using is more common in patients. ${ }^{22}$ And in another survey it is found that $44 \%$ of discharged patients have been prescribing at least one unnecessary drug. ${ }^{23}$ Similarly, chronic disease patients are referring more than one physician and prescribing drugs unaware of another are accepted reason for multidrug using. ${ }^{22}$

In our country, an important reason for multidrug using is habit of drug using without going doctor examination. Family physicians who are the first contact point of patients with the changed system in Turkey, can stop the unnecessary drugs and prevent usage of multidrug while they are making repeated appointments and getting more information.

\section{CONCLUSION}

We are of the opinion that, in our country where the costs of drugs where are gradually increasing, family physicians can reduce the rate of multiple drug use by way of managing both acute and chronic diseases simultaneously through a successful cooperation with their patients. Therefore, the sociodemographic status of patients with chronic diseases as well as the medications they're currently using should be questioned thoroughly during their admittance to the hospital. The physicians should also discontinue unnecessary medications with professional guidance and inform them about adverse effects of the drugs.

\section{REFERENCES}

1. Viktil KK, Blix SS, Moger TA, Reikvam A. Polypharmacy as commonly defined is an indicator of limited value in the assessment of drug-related problems. BJC Pharmacology2007;63:187-95.
2. Moriarty F, Hardy C, Bennett K, Smith S, Fahey T. Trends and interaction of polypharmacy and potentially inappropriate prescribing in primary care over 15 years in Ireland: a repeated crosssectional study. BMJ Open 2015;5(9):e008656.

3. Gokce Kutsal Y, Barak A, Atalay A, Baydar T, Kucukoglu S, Tuncer T, et al. Polypharmacy in the elderly: a multicenterstudy. J Am Med Dir Assoc 2009;10(7):486-90.

4. Wettermark B, Godman B, Neovius $\underline{\mathrm{M}}, \underline{\text { Hedberg N}}$, Mellgren TO, Kahan T. Initial effects of a reimbursement restriction to improve the cost-effectiveness of antihypertensive treatment. Health Policy 2010;94(3):221-9. 10.1016/j.healthpol.2009.09.014. Epub 2009 Oct 29.

5. Taskın SC, Aslan Karaoglu S,Evcil Toprak D. Evaluation of polypharmacy and complementary therapy use in patients $\geq 65$ years, attending to Family Medicine Outpatient Clinic of Sisli Etfal Training and Research Hospital.Turk Aile Hek Derg 2014;18(1):35-41.

6. Venturini CD, Engroff P, Ely LS, Zago LF, Schroeter G, Gomes I, et al. Gender differences, polypharmacy, and potential pharmacological interactions in the elderly. Clinics (Sao Paulo) 2011;66(11):1867-72.

7. Hofer-Dückelmann C. Gender and polypharmacotherapy in the elderly: a clinical challenge. Handb Exp Pharmacol 2012;(214):169-82.

8. Hajjar ER, Cafiero AC, Hanlon JT. Polypharmacy in elderly patients. Am J Geriatr Pharmacother2007 Dec;5(4):345-51.

9. Çakmur H. Factors affecting polypharmacy in elderly in two different (Kars-Izmir) cities of turkey. Turkiye Klinikleri J Med Sci 2014;34(1):71-80. doi: 10.5336/medsci.201336059 .

10. Dedeli O, Karadakovan A. Investigation of complementary and alternative medicine practice and drug use in the elderly. Spatula DD 2011;1:23-32.

11. Solmaz T, Akın B. Medication use and ability of selfmedication use in elderly living at home. TurkishJournal of Geriatrics 2009;12:72-81.

12. Loyola Filho AI, Uchoa E, Firmo JO, LimaCosta MF. [Influence of income on the association between cognitive impairment and polypharmacy: Bambuí Project]. Rev Saude Publica 2008;42(1):89-99.

13. Odubanjo E, Bennett K, Feely J. Influence of socioeconomic status on the quality of prescribing in the elderly a population based study. Br J Clin Pharmacol 2004;58(5):496-502.

14. Haider SI, Johnell K, Weitoft GR, Thorslund M, Fastbom J. The influence of educational level on polypharmacy and inappropriate drug use: a register-based study of more than 600,000 older 
people. J Am Geriatr Soc 2009;57(1):62-9. doi: 10.1111/j.1532-5415.2008.02040.x. Epub 2008 Nov 14.

15. Patterson SM, Hughes C, Kerse N, Cardwell $\mathrm{CR}$, Bradley MC. Interventions to improve the appropriate use of polypharmacy for older people. Cochrane Database Syst Rev 2012 May 16;(5):CD008165.

16. Esengen $\mathrm{S}$, Seckin U, Borman $\mathrm{P}$, Bodur $\mathrm{H}$, Gokce Kutsal Y, Yucel M. The assessment of functional cognitive impairment and drug consumption in a group of elderly residents of a nursing home. Turkish Journal of Geriatrics 2000;3:6-10.

17. Diker J. Chronic diseases and drug use in elderly over 65 years in the körfez health center 6 as well as in the one at Yüzbasılar in the province of Kocaeli.Turkish J Geriatrics 2000;3:91-7.

18. Ozbek S, Kaya E, Tekin A, Doğan S. Medication compliance in elderly. Turkish J Geriatrics 2006;9:177-81.
19. Akın B, Emiroglu N. Mobility related disability and associated factors in the elderly living at home. Turkish J Geriatrics2003;6(2): 59-67.

20. Yesilbalkan OU, Karadakovan A. The frequency of falls in elderly individuals living in Narlidere rest home and the evaluation of the affecting factors. Turkish J Geriatrics 2005;8:72-7.

21. Peterson C,Gustafsson M. Characterisation of drug-related problems and associated factors at a clinical pharmacist service-Naive Hospital in Northern Sweden. Drugs Real World Outcomes 2017;4(2):97-107.

22. Yesil Y, Cankurtaran M, Kuyumcu ME. Polypharmacy. Klinik Gelişim 2012;3:18-23.

23. Hajjar ER, Hanlon JT, Sloane RJ, Lindblad CI, Pieper CF, Ruby CM, et al. Unnecessary drug use in frail older people at hospital discharge. J Am Geriatr Soc. 2005; 53: 15181523. 